\title{
EURASIP Journal on Embedded Systems now publishing with SpringerOpen
}

\author{
Zoran Salcic
}

As the Editor-in-Chief, it is my pleasure to open this new Chapter in the development of EURASIP Journal on Embedded Systems. After five years since its foundation and publication within Hindawi publishing, the Journal has just been transferred to Springer and will be published on the SpringerOpen platform. The first five years were exciting as a part of a pioneering effort to create a journal on a highly contestable topic within the relatively inexperienced publisher. However, with the joint work of the Editorial board, the publisher, the support of EURASIP and numerous enthusiastic authors and contributors, the EURASIP JES has found its way to the scientific community and has grown in a respectable place for exchange of the most recent ideas and results in the broader area of embedded systems. The journal successfully attracted many special issues ranging from very theoretical to very application oriented, as the area of embedded systems is.

Now, the journal is facing an even more exciting period by being transferred under umbrella of a well known and trusted Springer brand, which will give a new momentum to the journal development and increase the visibility and impact on research community. Recent changes and additions to the Editorial board are on the lines of the strengthening in terms of reputation and geographical presence, quality of contributions and peer-reviews, which will continue in the same direction in future. By being open, JES will be available to the widest audience and make a way to all corners of the world. At the same time, with the Springer's help and resources, as well as excellent web presence, the journal has chance to develop even faster and become one of the major intersection points and relevance for the researchers around the world. It will continue its expansion and presence in all indexing sources without interruption.

Finally, we can reassure all the authors and contributors who submitted their manuscripts earlier that they

Correspondence: z.salcic@auckland.ac.nz

The University of Auckland, New Zealand will be processed with the usual speed and urgency and as smoothly as possible. All already published and accepted papers will be hosted on the SpringerOpen platform as well as become available through SpringerLink, thus becoming part of the huge Springer's publication portfolio.

We are looking forward to receiving new contributions and continuing collaboration with the previous contributors to the journal. We are also looking forward to liaising with broad and focused research events and at the same time encourage researchers to propose special issues on all topics within JES's scope. We are open for all forms of collaboration with research community as long as they contribute to the quality of the final product, publications.

Zoran Salcic

The University of Auckland, New Zealand

Received: 20 March 2011 Accepted: 21 April 2011 Published: 21 April 2011

doi:10.1186/1687-3963-2011-1

Cite this article as: Salcic: EURASIP Journal on Embedded Systems now publishing with SpringerOpen. EURASIP Journal on Embedded Systems 2011 2011:1.

Submit your manuscript to a SpringerOpen ${ }^{\circ}$ journal and benefit from:

- Convenient online submission

- Rigorous peer review

- Immediate publication on acceptance

- Open access: articles freely available online

- High visibility within the field

- Retaining the copyright to your article

Submit your next manuscript at $>$ springeropen.com 